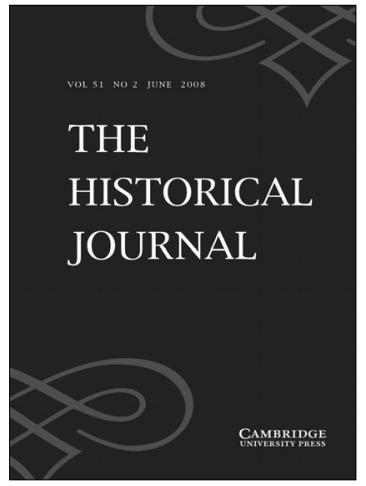

The Historical Journal

is available online at:

http://journals.cambridge.org/his

To subscribe contact

Customer Services

in Cambridge:

Phone +44 (0)1223 326070

Fax +44(0)1223 325150

Emailjournals@cambridge.org

\section{in New York:}

Phone+1(845) 3537500

Fax +1 (845) 3534141

Email

subscriptions_newyork@cambridge.org

\section{The \\ Historical Journal}

\section{Editors}

Julian Hoppit, University College London, UK

Clare Jackson, University of Cambridge, UK

\section{Editor (Reviews)}

William O'Reilly, University of Cambridge, UK

The Historical Journal publishes papers on all aspects of British, European, and world history since the fifteenth century. The best contemporary scholarship is represented. Contributions come from the UK, continental Europe, North America, and elsewhere. The journal provides a forum for younger scholars making a distinguished debut as well as publishing the work of leading historians.

\section{Price information is available at: http://journals.cambridge.org/his}

\section{Free email alerts}

Keep up-to-date with new material - sign up at http://journals.cambridge.org/alerts 


\section{CAMBRIDGE}

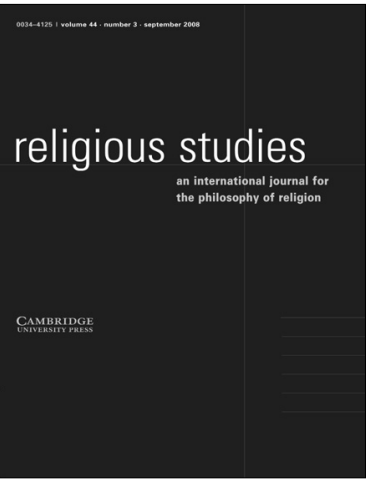

\section{Religious Studies}

is available online at:

http://journals.cambridge.org/res

To subscribe contact

Customer Services

in Cambridge:

Phone +44 (0)1223 326070

Fax +44 (0)1223325150

Email journals@cambridge.org

\section{in New York:}

Phone +1 (845) 3537500

$\mathrm{Fax}+1$ (845) 3534141

Email

subscriptions_newyork@cambridge.org

\section{Religious Studies}

An international journal for the philosophy of religion

\section{Editor}

P. A. Byrne, King's College London, UK

Religious Studies is an international journal devoted to the problems of the philosophy of religion as they arise out of classical and contemporary discussions and from varied religious traditions. Space is devoted to articles, of which more than 25 are published each year, and the journal also contains an extensive book review section, which includes review articles and book notes as well as normal-length reviews.

\section{Price information is available at: http://journals.cambridge.org/res}

\section{Free email alerts}

Keep up-to-date with new material - sign up at http://journals.cambridge.org/alerts

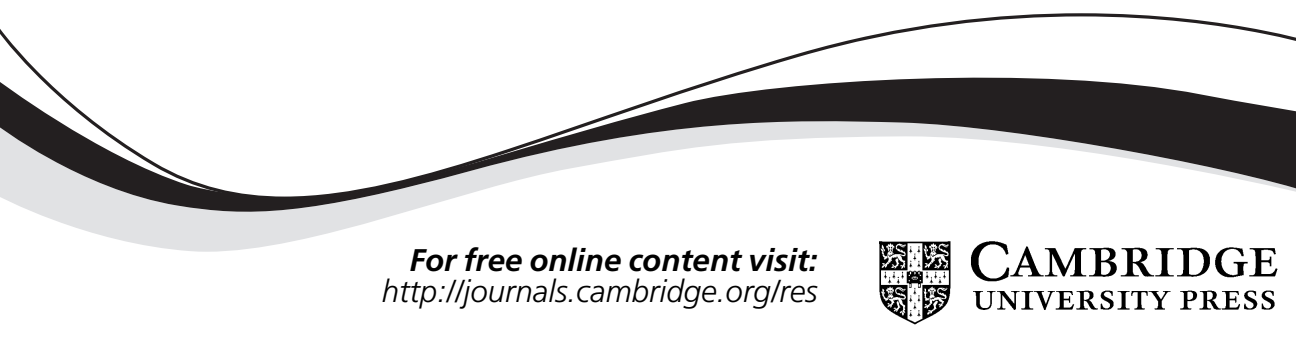




\section{Copying}

This journal is registered with the Copyright Clearance Center, 222 Rosewood Drive, Danvers, MA oI923, USA. Organizations in the USA who are also registered with the C.C.C. may, therefore, copy material (beyond the limits permitted by sections Io7 and Io8 of US copyright law) subject to payment to the C.C.C. of the per-copy fee of \$12.oo. This consent does not extend to multiple copying for promotional or commercial purposes. Code 0022-0469/og. ISI Tear Sheet Service, 350 i Market Street, Philadelphia, PA I9Io4, USA, is authorised to supply single copies of separate articles for private use only. Organizations authorized by the Copyright Licensing Agency may also copy material subject to the usual conditions. For all other use, permission should be sought from Cambridge or from the American Branch of Cambridge University Press.

This journal is included in the Cambridge Journals Online Service which can be found at www.journals.cambridge.org. For further information on other Press titles access www.cambridge.org.

This journal issue has been printed on FSC-certified paper and cover board. FSC is an independent, non-governmental, not-for-profit organization established to promote the responsible management of the world's forests. Please see www.fsc.org for information.

(C) Cambridge University Press, 2009

\section{CAMBRIDGE UNIVERSITY PRESS}

The Edinburgh Building, Cambridge $\mathrm{CB}_{2}$ 8RU, United Kingdom

32 Avenue of the Americas, New York, NY ioor3-2473, USA

477 Williamstown Road, Port Melbourne, VIC 3207, Australia

Ruiz de Alarcón I3, 280I4 Madrid, Spain

Dock House, The Waterfront, Cape Town 8oor, South Africa 


\section{The Journal of Ecclesiastical History}

Volume 6 o Number 4

October 2009

\section{GonTents}

\section{Articles}

The Other Saint Bernard: The 'Troubled and Varied Career' of Bernard of

Abbeville, Abbot of Tiron

KATHLEEN THOMPSON

A Glazing Scheme for Archbishop John Stafford

KATE HEARD

Rebuilding the Temple: James Pilkington, Aggeus and Early Elizabethan Puritanism

KARL GUNTHER

The Theological Origins of Jonathan Edwards's Philosophy of Nature

AVIHU ZAKAI

Law, Morality and Secularisation: The Church of England and the Wolfenden Report, 1954-1967

MATTHEW GRIMLEY

REVIEWS

Corrigendum

Books REGEIVED

Authors' AdDresses

Cambridge Journals Online

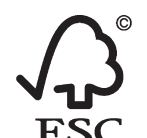

